Hywel Dix

\title{
AUTOFICTION, COLONIAL MASSACRES AND THE POLITICS OF MEMORY
}

Keywords: postcolonial literature; history; colonial massacres; Fred D'Aguiar; Kamila Shamsie; Jackie Kay; autofiction

Abstract: I argue that the emerging genre of autofiction provides a number of useful techniques and methods by which postcolonial writers engage with the politics of memory in their depiction of a number of largely forgotten brutalities committed by the European imperial powers during the colonial era. More specifically, two of the elements of autofictional practice that have been of particular interest to postcolonial writers are its capacity to mediate between individual and collective forms of memory on the one hand; while also radically destabilizing notions of absolute truth and authenticity on the other. Drawing on research into the relationship between writing and forms of public commemoration, the article analyses Fred D'Aguiar's portrayal of the killing of African slaves thrown overboard the slave ship Zong in 1781 in Feeding the Ghosts (1997); Kamila Shamsie's depiction of the massacre of demonstrators protesting against colonial rule in India in Peshawar in 1930 in A God in Every Stone (2014); and Jackie Kay's homage to the sinking of the SS Mendi, a ship carrying southern African non-combatant personnel to assist in the British effort in World War One in "Lament for the Mendi Men” (2011). It will suggest that even though these texts are not strictly works of autofiction, the techniques afforded by that genre are useful to those writers seeking to draw attention towards a number of neglected historical events. Colonial massacres, enslavement of people and naval disasters during the imperial period have received far less historical or cultural memorialization than other more widely recognized historical events such as VE Day or the Somme. By establishing these events as being culturally and morally important to remember, the article will argue, autofiction provides a number of tools for engaging with the politics of public memory and commemorative events in the present.

\section{On Memory and Memorials}

The present article is about collective traumas and how we remember or neglect to remember them. It is about a series of traumatic events in the colonial past, and the ripples, after effects and implications those events have for how we think about the construction of a cosmopolitan, racially sensitive and egalitarian society in the present. It is also about the literary and artistic representation of those events, and how such representation brings forward various means of challenging the cultural amnesia by which certain moments in history come to be lodged in the collective consciousness as objects of commemoration, even celebration, while others are left to fade into the

\footnotetext{
* Bournemouth University; UK.
} 
Trauma, Narrative, Responsibility

background. Parts of the article draw on established elements of postcolonial theory and scholarship. Occasionally it will draw attention to the paratexts of the novels discussed because those paratexts play an important role in the framing and extratextual positioning of the stories they tell, although the theoretical evaluation of paratexts has yet to be fully applied to the field of postcolonial studies as such. Finally, the paper will explore the somewhat newer genre known as autofiction in relation to how we remember colonial atrocities. It will argue that autofiction draws attention to the fraught nature of the process of remembering and therefore has potentially interesting things to add to the discussion of how we collectively remember traumatic events that have been neglected for decades, if not centuries.

The commodification of collective cultural memory is a process that has become manifest in the huge growth over the past fifty years of mechanisms and apparatuses devoted to creating and marking anniversaries, festivals and other kinds of memorial activities in celebration of different events, people or actions in the historical past. Ostensibly, such anniversaries require not only an inaugural event, person or action to refer back to, but also a cultural construction of what precisely about that event, person or action is to be celebrated rather than celebrating other people or events or different aspects of the same event. Of course, it is some years since Hayden White established that selections of this kind are implied in the writing of any historical narrative, making claims to absolute truth untenable; and Benedict Anderson argued that the collective decision to emphasize "this day, not that" was a means by which historical narratives were pressed into the service of nation building through recourse to the construction of a perceived common history during the nineteenth century (Anderson 35). But the positions adopted by White and Anderson on the narrativization of collective memory are given fresh impetus by the more recent trend towards contemporary re-enactment and other forms of public memorial of historical events.

In a survey of different kinds of memorial event, for example, William Johnston argues that commemorative events have increasingly been organized and disseminated by educational, arts and cultural institutions in ways that vary according to the forms of public culture and collective self-imagining that predominate in different countries. In this sense, commemorative occasions organized to mark particular anniversaries of prior people, events or inventions have become incorporated into what Robert Hewison had already characterized as the "heritage industries" more generally and hence into the commercialization of culture (Hewison 12). Indeed, there seems to be a conscious echo of Hewison's heritage industry in Johnston's description of the "Commemoration Industry" and the cultural capital such an industry brings to particular organizations and perceived cultural leaders (Johnston 63). It is also worth drawing attention to the relationship between the memorialization business and the process of literary and artistic canonization. For an author's centenary to be worth marking, he or she must have been considered a major artistic or intellectual figure. Conversely, the act of celebrating the centenary then has the effect of reinforcing this starting assumption. Thus the argument rapidly becomes circular: the centenaries or comparable anniversaries of certain authors are celebrated because they are known to be geniuses; and they are known to be geniuses because they are celebrated. 
As with the literary canon, so it is with the historical canon. Through the process of canonization, certain events become lodged much more prominently in the collective consciousness than certain others, and how this occurs is clearly a complex cultural process often related to dominant ideologies within individual nations and cultures. There has been a huge number of events and activities over the past five years in commemoration of two world wars, which remain cornerstones of the imperial ideology in Britain even today. The extent to which the celebration of these things has come to feel natural and self-evidently important so that people rarely question the impulse to do so is an index of how entrenched that ideology still is. But of course its effective functioning as ideology requires that the selective remembering of historical events is accompanied by a corresponding forgetting of some of the more morally ambivalent components of those events - as we will see. In a different context, Ekaterina Haskins has argued in a reading of the American memorial events that cropped up in the aftermath of 9/11, the invasions of Afghanistan and Iraq; and Hurricane Katrina, that if they are handled sensitively, dialogically and with openness towards the possibility of diverse interpretation and meaning, such commemorations can help to lay the terrain "toward a participatory memory culture" (Haskins 117). There is a potential connection between the impulse to commemorate and challenges to the imbuing of history with imperial ideology - but only if a new form of memorial culture can be developed.

\section{The Zong Massacre and Feeding the Ghosts}

The first example to be discussed is the so-called Zong Massacre of 1781. The Zong was a Liverpool-based sailing ship carrying a cargo of slaves from West Africa to Jamaica which got lost and as a result of taking longer than anticipated to complete the voyage, ran out of water. The Zong's crew threw the slaves overboard and left them to drown, to conserve water for other passengers and in order to claim the insurance value of the slaves, as stock, which would have been lost had they simply died onboard. When the insurers of the Gregson syndicate (which controlled the ship) refused to pay, an important court case took place. Initially it was ruled that slaves were mere cargo and so could be claimed on insurance in this way. Lord Mansfield subsequently ruled against the slave syndicate, mainly on the grounds that navigational errors by the crew had been the cause of the original difficulties. Because it had a certain prominence at the time, the Zong massacre and court case have been seen as important steps on the way to abolition even though questioning the morality of slavery as such barely featured in the trial. Today, the Zong is nowhere near as well known as, for example, the Battle of Hastings, the Battle of Waterloo, the Battle of Britain or any number of other incidents that have generally been assimilated to a heroic narrative of Britain's history. This is no doubt because even the most fervent revisionists of history would struggle to make anything even vaguely heroic out of it, and so it has instead simply been ignored, filtered out of the history that is passed on. This is absolutely in-keeping with so much of the history, and so many of the specific massacres, violations and traumas of the colonial period.

The Zong is the subject of Fred D’Aguiar's 1997 novel Feeding the Ghosts, a very powerful and moving invocation of both the massacre and the trial. The novel 
functions as a counter-monument, a monument in fiction that deviates from the ideological construction of the imperial past that dominates the memorial culture still prevalent in Britain. Part One depicts the Zong's Captain Cunningham deciding to throw sick slaves overboard (and claim on insurance) in order to maintain supplies and complete the mission. It also introduces a fictional human element in the relationship between the first mate Kelsal, who reluctantly fulfils the order, and a female slave Mintah who had known him, and nursed him through sickness at a Danish missionary station prior to her capture. When he cannot tolerate her insubordination of calling his name, she too is thrown into the sea, only to climb back aboard. She is then helped by the sympathetic assistant cook, Simon, and organizes other slaves in an attempt to resist their mass slaughter. For this they are eventually punished - not by being thrown overboard, because that would be to throw away the high price they would command in the Americas - but by other forms of violence and brutality.

The relationships between Mintah, Kelsal and Simon render the historical narrative perhaps more vivid than subsequent legal accounts alone. They raise an ethical question about who has the right to tell the story and also a practical question about doing so, since so much of the historical event depends on legal records in which very few of the slaves are even named. How then can they be portrayed in fiction in either a moral or a pragmatic way? Through Mintah, D’Aguiar can be said to have constructed an oppositional voice, a voice of the other in Aquinas's sense. That is, although the relationship between Mintah and Kelsal is fictionalized, the novel creates a space from which the subjectivity and human experience of people like her can be advocated in a way that would not today be possible in any other form simply because the stories are lost. Indeed, in the legal hearing in Part Two of the novel, the character Simon surprises Captain Cunningham and Kelsal by bringing to the court a diary written by Mintah recording the atrocities on board the Zong. It is disregarded by Lord Mansfield who rules that the Captain was right to jettison the damaged 'stock'. That is, Mintah's record is not taken into account at all: if anything, the fact that she could read and write is unacceptable to the authorities as it makes it hard for them to deny their common humanity with her - a denial which is the very basis of their claim for the insurance value of human beings as objects.

Part Three of Feeding the Ghosts jumps to the year 1833 - the year of the ending of slavery in Jamaica - and as part of the process of creating a space from which the voice of the other can be discerned, it takes the form of a monologue constructed by D'Aguiar for Mintah. In the interim, we learn, she had been sold into slavery in Maryland but her owners, on learning she could read and write, had made her teach their children. After spending years helping slaves to escape to the northern states, she had become known to the authorities and so she had saved money, bought her freedom and run away to Kingston, Jamaica, where she had bought planted a tree for all of the 131 victims of the Zong. Her beating on the Zong years earlier had so damaged her that she has not been able to have children, but she runs a Sunday school and is celebrated on the day of the ending of slavery in Kingston as a heroine of the anti-slavery struggle. She daydreams that Simon - who had helped her on the ship will come to the celebration parade. But history is not full of such simple happy endings. Instead, on the day after the parade, the wood of her house catches fire and 
she is consumed by flames - setting free the souls of the victims memorialized in her carvings.

D'Aguiar's depiction of Mintah bespeaks a number of important features of this kind of historical reconstruction in fiction of the violent and traumatic nature of the colonial past. There are the twin impulses to know and record testimony for the future but also the awareness and sensitivity that knowledge can be a form of burden. "I go to sleep knowing I have to write everything that happens to me and everyone around me" (D’Aguiar 191). The impulse to remember is juxtaposed with the difficulties inherent in memory and telling the truth requires that we know what it is, which is not easy. "I have a list of names. I know who did what to whom. But my detailed knowledge has not made an iota of difference to history or to the sea. All the knowledge has done is burden me” (D’Aguiar 229). In and through the novel, these twin and sometimes contradictory impulses are elevated from the level of Mintah's individual consciousness and instead are presented as a matter for collective cultural re-imagining. As we have seen, the Zong massacre is nowhere near as well-known as other episodes in colonial history which have proven more amenable to incorporation within a benign narrative of national development and self-fashioning. This means that even when there is a genuine desire to remember and commemorate it is not necessarily easy to know what is being commemorated. As a powerful symbol of this complexity, D'Aguiar employs the metaphor of the wood carvings Mintah uses to tell the story of the drowned slaves. She keeps pieces of wood pulled from the sea as figures to represent each of the victims, because the ghosts of the past are hungry and will be forgotten if no effort is made to feed their memory. But these figures are by their nature abstract, non-verbal and only indirectly expressive of the event they are chosen to express. This means that casual observers are prone to overlook their symbolic meaning altogether:

My visitors do not know what to look for when I ask them to select a block that they like so that I can convert it to a shape they admire. They pick up a piece of wood nearest to their hand, and when I say why did you choose that particular piece they shrug or admit it was the closest. But on further questioning they mention the pattern of the grain or the tone or even the size of the block. If only they could see that what they are laying their hands on is a treasure, that it harbours the past, that it houses the souls of the dead and that the many secrets of the earth are delivered up in it (D'Aguiar 208).

This representation of Mintah's efforts to create vernacular monuments in tribute to the dead shows that the process by which an event becomes fixed in the common consciousness is a difficult one. It flows like water along paths of least resistance. Where we don't know what is being remembered, we also can't know how to remember and instead of a monument to lost souls we see only bare blocks of wood. To put it another way, there are in existence myriad narratives in film, fiction, art and literature of those episodes in the colonial history that have received a high degree of cultural consecration owing to their perceived position in the historical narrative. Since there are existing recognizable and widespread prototypes for such representations, it is easier for new variations on the already-existing themes to gain a foothold than it is for new forms of monument, referring to qualitatively different 
Trauma, Narrative, Responsibility

kinds of experience, to take hold. We recognize portrayals of VE Day, Dunkirk or the Somme so much more readily than we do this representation of the Zong partly because we have already seen them represented so many more times before whereas this feels new to us and not only new but troubling and disturbing to our sense of who we are. And this newness is not a historical accident; it results from the fact that the story itself has not received the same level of attention as those other stories. It results, that is, from conscious choice and can only be counteracted through specific intervention.

Apparently mindful of the tendency for historical narratives to flourish more effectively if they are filtered through an always-already familiar lens, D'Aguiar himself attempts to do precisely this with Mintah. Her name, her story, her very identity are all invented. And having been invented, they are framed not by further invention, or through recourse to the historical archive, but through cultivating an implicit connection to a prior cultural slave - that of Spartacus:

My name was not mine any more. It belonged to the sea. I asked the sick their names and heard mine instead. "Mintah," they seemed to say. Death. And my name spread among the rest of the men, women and children [...] The captain cursed them and ordered his crew to clear the deck, and the crew beat them back. But not before ten had gone. Not bound. Mintah. Not thrown. Mintah. Jumped. Mintah. Come and get us. Mintah. Here we come. Ready or not. Mintah. Make room for us. Mintah . . . (D’Aguiar 213).

This representation of the name Mintah coming to stand in for every slave resisting massacre, every victim and every person struggling in solidarity against violence is strongly redolent of the iconic 'I'm Spartacus' scene from Stanley Kubrick's 1960 film of that name. The point is not simply that one portrayal of a slave rebellion (against Roman legions) is shown to have a degree of congruence with the portrayal of another rebellion (against British slave traders), but that for all its Hollywood melodrama the prior representation provides a kind of model following which the later might be able to gain entry into the artistic and historical canon from which it, and the event it depicts, have been so painfully excluded.

To counteract this exclusion, D'Aguiar includes a paratextual epilogue to the novel, apparently spoken by Mintah but a Mintah who should now be seen as a compound figure representing the myriad injustices, stories and voices that were silenced by the history the novel records. "Men, women and children are thrown overboard by the captain and his crew. One of them is me. One of them is you. One of them is doing the throwing, the other is being thrown. I'm not sure who is who, you or I" (D’Aguiar 229-30). This epilogue politicizes the story by elevating it onto an existential plane that brings all the difficulties involved in the narrative's implicit desire for a settling of accounts into the present. Rather than a story of then and now, the register is shifted to become one of you and me. In this way, connections to a neglected episode in the distinct past are forged and troubling questions are raised about how we remember it in the present. 


\section{The Peshawar Massacre in A God in Every Stone}

If the allusion to Spartacus suggests an implicit parallel between the slavery of ancient Rome and eighteenth-century Britain, that same method of pointing up the congruence between one period of imperialism and another is rendered much more explicit and sustained by Kamila Shamsie in her 2014 novel A God in Every Stone. Using the metaphor of archaeology, Shamsie juxtaposes the period of the Persian empire, whose boundaries connected modern day Europe to the Indian subcontinent, with the British.

A God in Every Stone starts in 1914 with Vivian Rose Spencer working on an archaeological dig in Labraunda, modern day Turkey, which was part of the region of Caria that was conquered by the Persian emperor Darius in about 500 B.C. The leading Turkish expert on the dig is Tahsin Bey, a friend of Viv's father, who dreams of finding the mythical circlet of Scylax, a treasure with which the Carian Scylax had been rewarded for undertaking a voyage to chart the course of the Indus River on behalf of his Persian conqueror Darius. Viv's sharing of this dream symbolizes her love of Tahsin Bey which is ultimately unconsummated, so that the novel represents the near impossibility of equal relationships between men and women of different races during the colonial period. When Viv's mother sends her to India as a gentlewoman's companion to escape the First World War, Tashin manages to send her an article from an archaeology journal that cryptically points her to a dig site in Peshawar as a possible place to look for the circlet. Viv arrives in Peshawar on the same train as Qayyum Gul, who along with his friend Kalam Khan is invalided out of the Indian regiments fighting on the British side at Ypres.

If the method of forging a comparison between the periods of two different empires is common to Feeding the Ghosts and A God in Every Stone, there is also a key difference in initial approach. D'Aguiar uses his novel to direct readers towards a traumatic event in the colonial past that has received too little attention or even acknowledgement. By contrast, the First World War, which Shamsie uses as the backdrop for her novel, has not been under-represented in the historical or artistic record. If anything, it is one of those events that has been rather too dominant as a reference point for the collective imagination in Britain. On the other hand, Shamsie is clearly interested in how it has tended to be represented and also appears to feel that the contribution of those Indian regiments has been insufficiently recognized. Thus through the creation of fictional characters such as Qayyum Gul and Kalam Khan she represents an important facet of the First World which has not figured as prominently in the way we think about the war as a whole as other stories and other lives have.

This unjust neglect is represented in the novel by how Qayyum and Kalam are treated. Qayyum is not even allowed to enter the hospital in Brighton where Kalam is treated, and although he highly values and appreciates the kindness of the English nurses, eventually an order is passed that no English women can treat Indian men and all the English nurses are removed. In fact, the British empire's paranoia over miscegenation and homoeroticism are both important themes in the novel, even though British officers father many children by the prostitutes on the Street of Courtesans in Lahore. Frequently Peshawari men are described as touching each other intimately, whether in a sexual sense or not, and the British men seem to frown on this 
and so make it illicit and somehow wrong. Qayyum and Kalam thus represent Indian subjects of the British empire having a deviant status inflicted on them not through anything they do but through the discursive construction of deviancy. In this way, Shamsie reveals her interest in how forms of representation play a major part in how our worldviews come to be constituted. When forms of representation are directed either towards or away from specific historical events in a disproportionate degree, powerful historical narratives emerge and these relate to what we value in the present. Contesting such narratives is difficult precisely because they are powerful and because a certain amount of historical momentum resides within them.

In the second half of A God in Every Stone, Shamsie directs her effort into challenging the historical narrative of one specific event, the Peshawar massacre of 1930, which like the Zhong massacre in Feeding the Ghosts, has been both under- and mis-reported. For this reason the profession of Shamsie's lead characters, archaeologists, is a controlling metaphor symbolizing the need to dig back through the historical record and look again at what is found there so that it can be re-interpreted in the present. By the time Viv returns to Peshawar to seek the circlet, Tahsin Bey has been killed in World War One. Instead, it is found by her friend Najeeb, another aspiring archaeologist, who is interested in her knowledge of ancient history, especially the Kushan period when the land of Ghandara (modern day Peshawar) had been part of the Persian empire. When the Carian people had rebelled against Persia, Scylax, despite earlier working for the Persian emperor Darius, had sided with them. Whether to side with their imperial masters or their own people becomes a fundamental dilemma for Najeeb and Qayyum too. But Najeeb gets caught up in a peaceful demonstration against British rule in the Walled City of Peshawar, which turns into a violent massacre of the protestors by the British army. Najeeb's lover Diwa is shot in the cross fire by British troops, and her turban is buried with the newlydiscovered circlet pinned onto it.

There is something iconic about this gesture, that hints again at the process by which certain events pass into the collective cultural memory while others are neglected, abandoned or forgotten. In D'Aguiar's novel the dramatic gesture of the slave Mintah cultivating a shared identity with all the other slaves had the effect of invoking all a similar moment in the prior fictional portrayal of a slave rebellion, Spartacus. This might be because D'Aguiar wants the Zhong story to be better known and because forgotten events of this kind more readily pass back into cultural memory if some kind of blueprint or model is available for them, preparing the ground. This may be why at the conclusion of A God in Every Stone, Shamsie also seems to follow the blueprint suggested by a prior filmic account of disaster - the 1997 film Titanic, and how it concludes with the older female character Rose throwing into the sea the jewel in pursuit of which the wrecked ship had been excavated. The quest for, and subsequent reburying of, the circlet of Scylax in A God in Every Stone seems to follow this trajectory in an explicit way. That is, the prior narrative provides a potential model for how the Peshawar massacre, which had been all-but forgotten in the common historical imagination, might be brought back into cultural currency, thereby challenging the ideological process by which it was allowed to grow fallow in the first place and engendering a form of restorative recollection. An afterword tells us paratextually that the official report into the Peshawar massacre dramatically under- 
Trauma, Narrative, Responsibility

estimated the number of people killed. In the novel, the city of Peshawar is pervaded over by the Hastings Monument, a real and tangible memorial to the first Governor of India and hence to the political and ideology control of imperialism. By disputing, in and through the means of fiction, the official report into the massacre, the novel serves as an alternative form of monument. It is a counter-monument that in the process of departing from those state-authored ideological accounts disputes them and disrupts them in order to bear witness to the dead and to the victims of imperialism.

\section{Autofiction and Poetry in Jackie Kay's Fiere and "Lament for the Mendi Men"}

In drawing attention to a series of gaps and lacunae in memory, elevated from an individual to a collective cultural plain, A God in Every Stone draws on some of the techniques otherwise associated with the genre of autofiction. Although there is little if any critical consensus on how to define this genre, it can be summarized as a form of biographical or autobiographical writing that dispenses with the rigid commitment to facts that we sometimes find in those forms, and instead writes memoir using the techniques of a novel, and specifically, a modernist experimental novel. These are techniques that place in question notions of absolute truth and critical objectivity and with them disappears also the assumption of a master narrative created by a sovereign self. In other words, memory is important to autofictional practice but the role and reliability of memory are questioned and critiqued in a very open and explicit way by it. This means that autofiction provides a different reading of the concept of memory to that which we find predominantly associated with the memorial industries. There, arbitrarily selected moments of the past are treated as if they are the logical occasion for some kind of intervention in the present. That the foundational event to which the anniversary refers took place in the way described by the memorial event is not generally opened up to critical interrogation so that its truth content is never questioned. By contrast, autofiction foregrounds the inherent unreliability of memory at both an individual and a collective level. Autofictional narratives therefore do not offer to tell the complete authentic truth of a past event as such, since it is committed to exploring the barriers of memory and emotion that obtrude between any event and its re-telling. Autofiction therefore shifts the parameters of representation away from questions of truth and accuracy towards questions of significance and value. Especially when they are dealing with past events of a collective or communal nature, autofictional narratives invite us to ask not What happened? but What does it mean for the people involved and for the people who come after them?

Strictly speaking, A God in Every Stone is not autofictional in the sense that was introduced by French novelist Serge Doubrovsky, the coiner of the term, for whom autofiction was defined by the fact that the work is designated a novel but where the writer appears under his or her own name. ${ }^{1}$ However, as Monika Fludernik's narratological research has shown, we tend to conceive of any narrative 'as told' unless it signals to the contrary (Fludernik 61). This took Fludernik in the direction of overhauling the distinction between first- and third-person narration, but in a different context it can usefully be applied to extend the definition of autofiction. If a story is

\footnotetext{
${ }^{1}$ See Doubrovsky 2013; Jones 2009; Grell 2014.
} 
conceived of as told, there has to be a teller, but in a third person narrative like $A$ God in Every Stone, it is difficult to ascertain precisely who this is. Lorna Martens points out that there is 'a whole series of ways' other than name alone by which an author can cultivate a symbolic identification with this or that character (Martens 51), and one such means is by asserting a direct personal stake in the subject matter. The afterword to A God in Every Stone is not associated with any character in the novel because it is to some extent external to it. But if we reject also the concept of a disembodied third-person voice, the only other possibility left is for us to consider the afterword to imply the voice of the author herself. Shamsie is clearly interested in addressing the historical blinkers that have prevented us from knowing much about the Peshawar massacre and in this small way inserts herself into a narrative that is nevertheless not about her as such. Thus there is a potentially fruitful convergence between autofiction and anti-imperial forms of writing in this case.

This convergence is in fact exactly what we find in Scottish writer Jackie Kay's 2010 memoir Red Dust Road, which documents Kay's attempts, having been adopted as baby, to find her birth mother and her Nigerian biological father. It is not a chronological narrative: it opens with her meeting her Nigerian father Jonathan in a hotel in Abuja in 2003, by which time she had already tried to meet her birth mother Elizabeth in the 1990s. These incidents are interspersed with memories of Kay growing up with her adoptive parents Helen and John in Scotland in the 1960s, 1970s and 1980s and repeated encounters with racist behaviour. The dusty road of Kay's title is not so much a physical road as a metaphor for how she imagines her father's Nigerian village will look when she gets there, how things might look if they had been different, and hence how her own life might have turned out if she had taken the road not travelled. In other words, she departs from a simple linear structure and suffuses the narration with highly impressionistic elements that feel true to her story even if they can never be verified in fact.

In a volume of poetry published the following year, Fiere (2011), Kay returned to the subject of her African ancestry. The poem "Burying my African Father" not only forms an intertext with Red Dust Road and her journey of discovery, but also acknowledges that she can only ever reach his ancestral village without him, because the brutal fact is that he had disowned her. She is obliged to bury him in her mind and is only able to learn the truth about his life by reconstructing her brief fragmented memories and expanding them into a poetic approximation of it. In the process of learning to accept the fact of her father's denial of her relationship to him, she simultaneously becomes more aware of her connection to her African heritage more generally. In other words, although it is necessary for her to let go of her relationship to her father this does not mean she cuts herself off from her African culture and ancestry overall; the more she lets go of one, the more immersed she becomes in the other. Thus she uses her poetry to modulate between individual and collective forms of memory and belonging. Since she never knew the precise individuals with whom she discovers a belated connection, the technique of approximating their lives, that is retrospectively recreating their stories and cultures in imaginative form, is highly important to her because it is the only means of asserting her kinship with them. 
Trauma, Narrative, Responsibility

This use of poetic approximation is most evident in Fiere in the poem "Lament for the Mendi Men", a poetic memorial to those who died onboard the SS Mendi, a ship carrying more than 800 mainly black non-combatant personnel from South Africa to act as auxiliary workers (as distinct from soldiers) in the Allied trenches during World War I, which sank after colliding with the Darro off the coast of the Isle of Wight in February 1917, with the death of 646 men, of whom 607 were black. In a way that recalls D'Aguiar's fictional reconstruction of the events onboard the Zong, Kay concisely portrays the atmosphere and mood on the Mendi at the time of the disaster:

The dark here was different from the African dark.

The fog carried the ghost's cloak of death,

a petrifying spectre, a spirit, a nightmare;

it was like nothing the men had ever seen before (Kay n.p.).

The sinking of the Mendi has been described as the worst naval disaster in both British and African history, and yet the fate of the drowned men onboard the Mendi is not widely known. Charlotte Williams has drawn attention to the tendency, when reconstructing the lives of people who have been marginalised from the historical record, to use the language of superlatives: "an endless round of 'firsttos' and 'beentos' boasting among ourselves" (Williams 47). Such superlatives are commonly applied in public memorials in the context of the commodification of memory and the memorial industries discussed above. In general, however, they turn out to be markers of superficiality rather than deep meaning and significance. What matters to Kay about the Mendi is not a question of whether or not it was the biggest maritime disaster in history, but the human experience of tragedy which cannot be summarized in this way:

Every man who sank down to the sea bed to be held by the sea bed's thick-lined body was a mother's son, a sister’s brother, a lover’s lover (Kay n.p.).

Kay's poem explicitly avoids any depiction of the war in Europe which was the context in which the disaster occurred and instead evokes an emotive, tactile response to it. Neither does she make exaggerated or hyperbolic claims for the significance or the importance of the even such as the first, the worst, the biggest of its kind. The only superlative she employs informs us that the darkness that swallowed up the African men was 'like nothing' they had ever experienced before and must presumably have been the more terrifying for its unfamiliarity.

On the other hand, although she does not wish to resort to the language of superlatives, Kay is interested in ensuring that men onboard the SS Mendi be remembered. In this sense, the poem "Lament for the Mendi Men" is her means of remembering the tragedy, even though she has no direct memory of it. This is something that autofiction can enable because it shifts memory from an individual 
entity to one that is collectively shared and passed on. Through such language, the poem becomes a form of memorial to the Mendi men, but one that differs in kind from those associated with the memorial industries. This is because the language of autofiction turns away from the emotional rhetoric associated with hegemonic forms of public memory and in doing so places meaning and significance themselves in active question. It is very notable, for example, that although monuments, memorials and anniversaries to maritime achievement abound throughout Britain and Europe, mainly in relation to imperial history, the SS Mendi remains much less widely honoured or even known about. Kay thus concludes with a call to action: "Now, now; / it is time to remember the dead" (Kay n.p. emphasis in original) and in doing so enacts a temporal shift from the moment at which the tragedy occurred to the present in which she 'remembers' it. The reason she attaches a high level of importance to it is not simply because it is a dark episode in history whose victims have been unjustly neglected, but because having recently reconnected with her own African heritage she feels that it is in some sense her own history. The italicization of the final lines seems to perform a further shift, not merely temporal but also figural, embodying a transition from an omniscient third-person narrative to a vocal first-person, Jackie Kay herself. It feels as if by the end of the poem she has added herself much more explicitly to the then-and-there of the event. Autofiction when applied in this way contests the dominant ideology that attaches more importance to certain events and lives than others and generates instead a series of counter-hegemonic narratives in relation to the past. "Lament for the Mendi Men" opens a new perspective on the communal nature of cultural memory and undertakes to re-inscribe a forgotten and neglected event into the collective consciousness by asking its readers to think about the event in the present rather than by insisting on the primacy of the original historical moment.

\section{Conclusion: The Construction of Memory}

This article had three objectives: first to draw attention to a series of violent atrocities committed during the imperial period which are not widely remembered in the present; second to explore how those events have been represented in imaginative works in the more recent past in order to create a series of counter-memorials that disrupt the established literary and historical record through the introduction of antihegemonic narratives; and third to draw attention to how some of the theoretical material associated with the study of paratexts on the one hand and autofiction on the other can be used to advance our critical understanding of this kind of writing beyond the already existing insights of critical postcolonial studies. The techniques by which D’Aguiar, Shamsie and Kay break down the distinction between inside and outside the fiction are highly paratextual, but paratexts are a form of writing that remain somewhat under-studied in postcolonial literature. Moreover, those same paratexts are also means by which the writers insert themselves into the narratives if not directly as participants then at the very least as stakeholders and critical witnesses, so that they can be said to deploy the forms and techniques otherwise referred to as autofiction. This is a conjunction worth making, because one of the effects of autofictive writing is to highlight not merely the unreliability of memory, but also the process by which memory is actively constructed and the means by which what is remembered either 
Trauma, Narrative, Responsibility

passes into the collective cultural consciousness or is filtered out. Thus these three writers draw on the techniques of autofiction to challenge the fact that the atrocities they portray have been subject to just such a filtering out of history.

\section{Works Cited:}

Anderson, Benedict. Imagined Communities: Reflections on the Origins and Spread of Nationalism. London: Verso, 1983. Print.

D’Aguiar, Fred. Feeding the Ghosts. London: Chatto \& Windus, 1997. Print.

Doubrovsky, Serge. “Autofiction.” Auto/Fiction 1.1 (2013): i-ii. Print.

Fludernik, Monika. The Fictions of Language and the Languages of Fiction. London: Routledge, 1993. Print.

Grell, Isabelle. L'autofiction. Paris: Armand Colin, 2014. Print.

Haskins, Ekaterina. Popular memories: commemoration, participatory culture, and democratic citizenship. Columbia, SC: University of South Carolina Press, 2015. Print.

Hewison, Robert. The heritage industry: Britain in a climate of decline. London: Methuen, 1987. Print.

Johnston, William. Celebrations: The Cult of Anniversaries in Europe and the United States Today. Abingdon: Routledge, 2017. Print.

Jones, Elizabeth H. "Autofiction: A Brief History of a Neologism.” Life Writing: Essays on Autobiography, Biography and Literature. Ed. Richard Bradford. Basingstoke: Palgrave Macmillan, 2009. 174-84. Print.

Kay, Jackie. Fiere. London: Picador, 2011. Print.

Martens, Lorna. "Autofiction in the Third Person, with a Reading of Christine BrookeRose's Remake.” Autofiction in English. Ed. Hywel Dix. Basingstoke: Palgrave Macmillan, 2018. Print.

Shamsie, Kamila. A God in Every Stone. London: Bloomsbury, 2014. Print.

White, Hayden. Tropics of Discourse: Essays on Cultural Criticism. Baltimore, MA: The Johns Hopkins University Press, 1985. Print.

Williams, Charlotte. Sugar and Slate. Aberystwyth: Planet, 2002. Print. 